\title{
MANAJEMEN PENDIDIKAN KARAKTER MABADI KHAIRA UMMAH DI SMK MAARIF 2 GOMBONG
}

\author{
Agus Salim Chamidi dan Bahrun Ali Murtopo \\ aschamidi@yahoo.co.id \\ bahrunalimurtopo@gmail.com
}

\begin{abstract}
This research is done for looking for formula of mabadi khaira ummah as a matter of character education in SMK Maarif 2 Gombong. Mabadi khaira ummah itself is concept and values of building good society resulted by Nahdlatul Ulama (NU). Research want to know how to manage mabadi khaira ummahal. Research is qualitative with interview, investigation, and documentation, and also combining snowball sampling and purposive sampling techniques which the headmaster as the first informant and then some persons as informants. The research is done on April-August 2014 and turn to be checked on August-September 2017. Results of research are that mabadi khaira ummah is managed by headmaster of SMK Maarif 2 Gombong, not only in a specific lesson but also in some activities of school regularly, and that the headmaster also leads and moves all components managementally. The other result is that this research can build a pattern of management of education.
\end{abstract}

Keywords: mabadi khaira ummah, management of education, leadership.

\begin{abstract}
Abstrak
Penelitian ini dilakukan untuk meneliti rumusan mabadi khaira ummah sebagai sebuah materi pendidikan karakter di SMK Maarif 2 Gombong. Mabadi khaira ummah itu sendiri merupakan konsep dan nilai-nilai tentang membangun masyarakat yang baik yang dihasilkan oleh Nahdlatul Ulama (NU). Penelitian ingin mengetahui bagaimana manajemen mabadi khaira ummahal. Penelitian ini bersifat kualitatif dengan wawancara, pengamatan, dan dokumentasi, dan juga menggabungkan teknik sampling snowball dan purposive sampling dengan kepala sekolah sebagai informan pertama dan kemudian sejumlah orang sebagai informan. Penelitian dilakukan AprilAgustus 2014 dan kembali diteliti untuk penguatan pada Agustus-September 2017. Hasil penelitian ini adalah bahwa mabadi khaira ummah itu dikelola oleh Kepala
\end{abstract}


SMK Maarif 2 Gombong, tidak hanya dalam mata pelajaran khusus tetapi juga dalam sejumlah kegiatan sekolah secara regular, dan bahwa kepala sekolah juga memimpin dan menggerakkan seluruh komponen sekolah secara manajerial. Hasil lain adalah bahwa penelitian ini dapat membangun suatu pola manajemen pendidikan.

Kata kunci: mabadi khaira ummah, manajemen pendidikan, kepemimpinan.

\section{A. Pendahuluan}

Fakta di lapangan, bahwa jatah alokasi waktu jam pelajaran pendidikan agama Islam (PAI) di Sekolah Menengah Kejuruan (SMK) hanya 3 jam pelajaran per minggu dari total 58 jam pelajaran. Itupun PAI menyatu dengan materi 'Budi Pekerti' dalam Kurikulum 2013. Prosentasenya sangat minim, sekitar 5\%. Akibatnya pengajaran agama Islam di SMK selama ini berlangsung terasa hambar. Agama Islam menjadi kurang terkait terhadap persoalan bagaimana mengubah pengetahuan agama Islam yang bersifat kognitif menjadi makna dan nilai yang perlu diinternasionalisasikan dalam diri peserta didik untuk bergerak, berbuat dan berperilaku secara kongkret-agamis dalam kehidupan praksis sehari-hari ${ }^{1}$. Dengan demikian kehadiran mata pelajaran lokal seperti Ke-NU-an di lingkungan Lembaga Pendidikan (LP) Maarif NU menjadi penting, walaupun nasibnya juga sama dengan jatah alokasi waktu hanya 2 jam pelajaran per minggu. Demikian halnya di SMK Maarif 2 Gombong, pemahaman dan praktek agama Islam pun menjadi terbatas oleh waktu jam pelajaran, dan karenanya diperlukan terobosan manajemental agar tujuan-tujuan penyelenggaraan pendidikan yang berkarakter dapat tercapai secara maksimal dan optimal. Apalagi di era globalisasi dan borderless, pendidikan sekolah secara umum harus berhadapan dengan kenyataan sosio-kultural yang kompleks. Terobosan manajemen pendidikan karakter berbasis kultur kearifan lokal menjadi urgen guna membangun kepribadian siswa.

Secara yuridis, Undang Undang Sistem Pendidikan Nasional Nomor 20 Tahun 2003, Bab $\mathrm{XV}$, Pasal 55, point 1 dan 2 menyebutkan bahwa (1)Masyarakat berhak menyelenggarakan pendidikan berbasis masyarakat pada pendidikan formal dan nonformal sesuai dengan kekhasan agama, lingkungan social, dan budaya untuk kepentingan masyarakat, (2)Penyelenggaraan pendidikan berbasis masyarakat mengembangkan dan melaksanakan kurikulum dan evaluasi pendidikan, serta manajemen dan pendanaannya sesuai dengan standar nasional pendidikan. Ini merupakan landasan normatif bahwa penyelenggaraan manajemen pendidikan dengan berbasiskan kearifan lokal tidak bertentangan dengan hukum dan undang-undang yang berlaku. Dengan demikian penyelenggaraan mata pelajaran dan kegiatan lain seperti Ke-NU-an, KeMuhammadiyah-an, dan lainnya merupakan keniscayaan yang sah dan sekaligus menjadi kebutuhan masyarakat itu sendiri.

SMK Maarif 2 Gombong bervisikan “menyiapkan siswa yang unggul dalam prestasi berdasarkan iman dan taqwa". Sekolah ini merupakan salah satu SMK di Kabupaten Kebumen,

1 Muhaimin, Paradigma Pendidikan Islam, Upaya Mengefektifkan Pendidikan Agama Islam di Sekolah, Bandung: Remaja Rosdakarya, 2004, hal. 168. 
yang berada di bawah naungan Lembaga Pendidikan (LP) Maarif NU Kebumen. Dalam kaitannya dengan upaya pendidikan karakter dan sebagai pelaksana kebijakan NU dalam bidang pendidikan formal, LP Maarif NU sudah menambahkan materi ke-NU-an dalam setiap satuan pendidikan yang diselenggarakan sesuai dengan Anggaran Dasar NU Pasal 18 ayat 6. Salah satu materi ke-NU-an yang wajib diberikan kepada peserta didik di lingkungan sekolah Maarif NU adalah tentang mabadi khaira ummah ${ }^{2}$ (disingkat MKU). Materi MKU ini berisi tentang prinsip-prinsip dasar moralitas dan karakter yang harus dimengerti serta diamalkan oleh setiap kader NU ${ }^{3}$. Rumusan MKU di SMK Maarif 2 Gombong pun hanya mendasarkan pada buku ajar mata pelajaran Ke-NU-an yang berjudul Ke-NU-an Ahlussunah Waljamaah MA/SMA/SMK Kelas XII, tulisan M. Faojin dan Noor Kholis, keluaran Lembaga Pendidikan (LP) Maarif PWNU Jawa Tengah, tahun 2011, halaman 4-9. Buku pegangan ini memuat pokok bahasan MKU dengan materi berupa lima butir nilai prinsipil karakter, yaitu: (1) al shidqu (memiliki integritas kejujuran), (2) al amānah wa al wafa' bi al 'ahdi (terpercaya dan menepati janji), (3) al ta'āwun (saling menolong), (4) al 'adälah (tegak lurus dalam meneguhkan rasa adil dan keadilan), dan (5) al istiqämah (konsisten). Sesuai dengan Peraturan Menteri Pendidikan Nasional (Permendiknas) Nomor 22 Tahun 2006, materi MKU di SMK Maarif 2 Gombong itu pun dirancang ke dalam bentuk silabus pembelajaran, rencana pelaksanaan pembelajaran (RPP), dan kesiapan bahan/ buku ajarnya. Adapun silabus pembelajaran materi MKU secara eksplisit tertuang dalam silabus mata pelajaran Ke-NU-an Kelas XII pada Kompetensi Dasar (KD) Nomor 1.2 yang berbunyi: "Menghayati Mabadi Khaira Ummah dan merefleksikannya dalam kehidupan sehari-hari", dan KD Nomor 4.2 yang berbunyi: "Mengamalkan dan menyebarluaskan Mabadi Khaira Ummah".

Permasalahannya adalah apakah materi MKU sebagai satu muatan pendidikan karakter dengan jatah alokasi waktu 2 jam pelajaran per minggu itu mampu mengemban tugas menginternalisasikan prinsip-prinsip dasar dan moralitas kepada peserta didik; dan apakah muatan-muatan yang terkandung di dalamnya telah dapat diimplementasikan dalam kehidupan peserta didik. Dengan jatah alokasi jam pelajaran yang sangat minim tentunya hal ini sangat tidak relevan dengan tujuan dan harapan. Maka dari itu, langkah-langkah yang manajemental itu urgen untuk direncanakan, dilaksanakan, diatur, dan dikontrol sehingga tujuan dan harapan kependidikannya dapat tercapai dengan baik sesuai dengan visi. Bagaimana mengetahui manajemen pendidikan karakter MKU di SMK Maarif 2 Gombong pun menjadi kebutuhan penting dan urgen. Harapannya adalah bahwa manajemen pendidikan karakter MKU ini kiranya dapat menjadi rujukan bagi sekolah dan lembaga pendidikan lain secara lebih luas.

Adapun pemilihan lokasi penelitian di SMK Maarif 2 Gombong setidaknya memiliki alasan bahwa sekolah ini: (1) menyelenggarakan kegiatan belajar mengajar (KBM) Ke-NUan materi mabadi khaira ummah (MKU), (2) memiliki Pondok Pesantren (PP) An Nahdliyah yang berlokasi di sebelah selatan kompleks sekolah, (3) bersetifikat ISO 9001:2008 pada bidang

2 Faojin M dan Noor Kholis, Ke-NU-an dan Ahlussunah Waljamaah MA/SMA/SMK Kelas XII, Lembaga Pendidikan Maarif NU Jawa Tengah, 2011, hal. 2

3 Faojin $M$ dan Noor Kholis, Ke-NU-an dan Ahlussunah Waljamaah MA/SMA/SMK Kelas XII, Lembaga Pendidikan Maarif NU Jawa Tengah, 2011, hal. 3 
manajemen pada tahun 2013, dan (4) melaksanakan tradisi khas NU seperti yasinan (membaca Al Qur'an Surat Yasin) tiap hari Jumat pagi sebelum kegiatan pembelajaran dilaksanakan, infak Jumat pagi, dan lainnya, yang nampak semuanya merupakan bagian tak terpisahkan dari pola manajamen pengembangan sekolahal.

\section{B. Bahan}

Penelitian ini bersifat kualitatif tentang bagaimana manajemen pendidikan karakter MKU diselenggarakan. Manajemen di sini dipandang sebagai aktivitas memadukan sumber-sumber pendidikan agar terpusat dalam usaha mencapai tujuan pendidikan yang telah ditentukan ${ }^{4}$. Manajemen pendidikan menjadi sebuah langkah-langkah aktif-operasional guna mencapai tujuan pendidikan, bukan sekedar kumpulan teori dan pemahaman belaka. Oleh karenanya, penelitian ini beranjak dari pemilihan informan kunci, yaitu kepala sekolahal. Kepala sekolah dipandang sebagai inti manajemen pendidikan di sebuah sekolahal. Wawancara mendalam terhadap kepala sekolah menjadi modal awal dan utama dalam penelitian ini. Membangun hubungan yang baik dengan informan kunci ini sangat diperlukan dalam penelitian ini. Selanjutnya penggalian informasi dan data mengarah secara khusus pada permasalahan bagaimana manajemen pendidikan karakter MKU diselenggarakan. Di sini penelitian mulai mempergunakan teknik purposive sampling sekaligus snowball sampling untuk mendapatkan sejumlah informan yang sesuai dengan tujuan penelitian. Selain mempergunakan teknik wawancara, penelitian juga melaksanakan observasi dan dokumentasi guna melengkapi informasi dan data penelitian.

\section{Hasil dan Pembahasan}

\section{Memahami Mabadi Khaira Ummah}

Konsep mabadi khaira ummah (MKU) secara historis lahir dari Nahdlatul Ulama (NU) yang merupakan sebuah organisasi kemasyarakatan keagamaan Islam khas nusantara Indonesia. Konsep MKU ini merupakan konsep besar dalam rangka pembentukan masyarakat yang ideal/ terbaik (khaira ummah). Adapun istilah khaira ummah berasal dari Bahasa Arab yang diambil dari ayat Al Qur'an Surat Ali Imran ${ }^{5}$ :

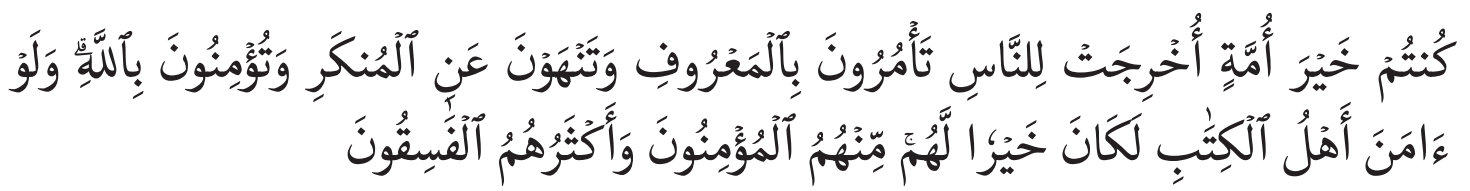

Artinya: "Kamu (umat Islam) adalah umat terbaik - khaira ummah - yang dilahirkan untuk manusia, (karena kamu) menyuruh (berbuat) yang makruf dan mencegah dari yang mungkar, dan beriman kepada Allahal. Sekiranya Ahli Kitab beriman, tentulah itu lebih baik bagi mereka. Diantara mereka ada yang beriman, namun kebanyakan mereka adalah orang-orang fasik".

Secara etimologi MKU terdiri dari tiga kata Bahasa Arab. Pertama adalah kata mabadi'

4 Made Pidarta, Manajemen Pendidikan Indonesia, Jakarta, Bina Aksara, 1998, hal. 4

5 QS.4: 11 
yang artinya landasan, dasar, atau prinsip. Kedua adalah kata khaira yang berarti terbaik atau ideal. Dan ketiga adalah kata ummah yang artinya masyarakat, bangsa atau rakyat ${ }^{6}$. Sedangkan secara epistemologi, MKU adalah prinsip-prinsip dasar yang digunakan untuk mengupayakan terbentuknya tatanan kehidupan masyarakat yang ideal atau terbaik, yaitu masyarakat yang mampu melaksanakan tugas-tugas amar ma'ruf nahi munkar. Dengan kata lain bahwa MKU merupakan konsep yang realistis dengan bersendikan amar ma'ruf nahi munkar. Adapun amar ma'ruf sendiri adalah mengajak dan mendorong perbuatan baik yang bermanfaat bagi kehidupan di dunia dan di akherat kelak, sedangkan nahi munkar adalah menolak dan mencegah segala hal yang dapat merugikan, merusak dan merendahkan nilai-nilai kehidupan ${ }^{7}$.

Berdasarkan uraian di atas, dapat disimpulkan bahwa tujuan utama dari gerakan MKU adalah untuk membentuk identitas personal yang mulia, baik dan bertanggungjawab dalam menjalankan peran-peran individual dan sosialnya ketika berinteraksi dengan individu ataupun komponen masyarakat lainnya. Gerakan MKU berorientasikan pada terbentuknya sumber daya pembangunan bangsa Indonesia yang jujur, amanah, komitmen, adil, saling bekerjasama, dan konsisten dalam menjalankan amar máruf nahi munkar demi terwujudnya kehidupan masyarakat yang sejahtera lahir batin dan diridlai Allah Tuhan Yang Mahaesa.

MKU sebagaimana sudah disebutkan di atas adalah (1) al shidqu, (2) al amānah wa al wafa' bi al'ahdi, (3) al ta'āwun, (4) al 'adālah, dan (5) al istiqāmahal. Kelima butir MKU tersebut merupakan satu kesatuan dari prinsip-prinsip dasar pembentukan khaira ummah (masyarakat ideal, terbaik, berperadaban). Kelima butir di atas merupakan satu kesatuan pedoman dalam berpikir, bertindak, dan bersikap. Selanjutnya kelima prinsip MKU ini dijelaskan dan dijabarkan menjadi lebih operasional sebagai berikut.

a. Al Shidqu ${ }^{8}$

Al shidqu berarti kejujuran, kebenaran, kesungguhan, dan keterbukaan. Adapun kejujuran adalah bersatunya kata dengan perbuatan, dan juga sinkronnya ucapan dengan pikiran ${ }^{9}$. Apa yang diucapkan secara lisan, harus sama dengan yang terbersit di dalam hati atau bathin. Jujur dalam hal ini berarti tidak plin-plan dan tidak dengan sengaja memutarbalikkan fakta atau memberikan informasi yang menyesatkan. Dalam hal ini, jujur juga bermakna jujur kepada diri sendiri.

Dalam pengertian ini, jujur juga bermakna jujur dalam setiap transaksi yang dilakukan, serta jujur dalam bertukar pikiran dan diskusi. Jujur dalam bertransaksi artinya menjauhi segala bentuk penipuan demi mengejar keuntungan pribadi. Sedangkan jujur dalam bertukar pikiran berarti ikhlas mencari mashlahat dan kebenaran dari manapun atau dari siapapun datangnya, serta bersedia mengakui dan menerima pendapat yang lebih baik ${ }^{10}$.

6 Atabik Ali dan Ahmad Zuhi Muhdlor, Kamus Krapyak Al-'Ashri Arab Indonesia, Cetakan 2, UD. Multi Karya Grafika, Yogyakarta, 1997, hal. 216, 867, 1589.

7 Endang Turmudi (Editor), Jejak Langkah NU dari Masa ke Masa, Jakarta, Luna Kreasindo, 2006, hal. 112.

8 QS.9: 119 sebagai salah satu dasarnya.

9 Abdul Mun’im, DZ, Piagam Perjuangan Kebangsaan, Jakarta: Setjen PBNU, NU Online, 2011, hal. 57.

10 Endang Turmudi (Editor), Jejak Langkah NU dari Masa ke Masa, Jakarta, Luna Kreasindo, 2006, hal. 115 
Jujur itu dalam menerima dan menyampaikan kebenaran itu bersifat personal maupun kolektif, sekaligus juga bersifat internal maupun eksternal. Artinya bahwa kejujuran itu harus menjadi prinsip dan sikap hidup orang perorangan, baik terhadap dirinya sendiri (internal) maupun terhadap pihak lain di luar dirinya (eksternal). Kejujuran juga menjadi prinsip dan sikap hidup kolektif sebuah keluarga, komunitas, kumpulan, masyarakat, atau sebuah bangsa, baik terhadap mereka sendiri (internal) maupun pihak lain (eksternal).

Dalam kejujuran ini tidak ada pembohongan, penipuan, dan penyesatan yang dilakukan secara personal maupun kolektif terhadap pihak lain baik itu personal maupun kolektif. Menjunjung tinggi kebenaran pun menjadi nilai pokok dan utama kejujuran ini. Prinsip al shidqu ini membentuk watak dan sikap selalu menjunjung tinggi kebenaran dan kejujuran dalam berpikir, bertindak, bekerja, berinteraksi sosial, dan berkarya nyata. Dengan al shidqu seseorang atau sekelompok orang dapat membangun kredibilitas ketika bekerjasama dengan pihak lain.

Dengan demikian, prinsip MKU al shidqu merupakan prinsip dasar yang menempatkan kebenaran dan kejujuran sebagai sendi utama. Kebenaran dan kejujuran ini merupakan prinsip dasar untuk membentuk karakter pribadi seseorang secara individual maupun secara sosialkemasyarakatan. Dengan kata lain, khaira ummah hanya dapat terbangun apabila al-shidqu ini menjadi pilarnya. Al-shidqu ini akan menciptakan sosok-sosok manusia yang memiliki kredibilitas (kepercayaan) yang tinggi.

Dalam dunia pendidikan prinsip al-shidqu ini tentunya harus menjadi prinsip bagi kalangan dunia pendidikan itu sendiri, baik pendidik, tenaga kependidikan, maupun peserta didik. Pendidik dan tenaga kependidikan harus memiliki kredibilitas dan kejujuran, dan menjunjung tinggi kebenaran untuk tujuan mendidik peserta didik menjadi lebih jujur, lebih menjunjung tinggi kebenaran, dan lebih memiliki kredibilitas dalam hidupnya. Proses pendidikan sebagai proses transfer dan internalisasi keilmuan dan ketrampilan (skills) tentunya sangat mengutamakan prinsip ini.

\section{b. Al amānah wa al wafa bi al 'abdi ${ }^{11}$}

Prinsip ini memuat dua istilah yang saling terkait, yakni istilah al amānah dan istilah al wafa' bi al 'ahdi. Adapun istilah yang pertama al amânah bersifat lebih umum, yang meliputi semua beban tugas yang harus dilaksanakan, baik yang didahului dengan akad perjanjian maupun tidak. Sedangkan istilah yang kedua lebih al wafa' bi al 'ahdi bersifat khusus, yakni beban tugas yang harus dipenuhi ketika sebelumnya telah diawali dengan perjanjian atau kesepakatan. Adapun penggabungan kedua istilah tersebut adalah untuk memperoleh satu kesatuan pengertian, yakni 'dapat dipercaya, setia dan tepat janji'.

'Dapat dipercaya' merupakan sifat yang diletakkan pada seseorang yang dapat melaksanakan beban tugas yang dipikulnya, baik tugas yang bersifat moral individual kepada Allah (diniyah) maupun yang bersifat moral publik saat berhadapan dengan pihak lain (ijtima’iyah). Dengan sifat ini seseorang akan menghindarkan diri dari segala bentuk penghianatan 
dan manipulasi tugas dan jabatan ${ }^{12}$. Justru 'dapat dipercaya' malahan menunjukkan prinsip setia dan tepat janji. Artinya, prinsip al amānah wa al wafa bi al 'ahdi ini menjamin integritas dan dedikasi seseorang ataupun sekelompok orang dalam menjalankan tugas dan wewenang.

Orang berintegritas menunjuk pada orang yang memiliki kepribadian yang jujur dan karakter yang kuat. Orang berdedikasi menunjuk pada orang yang memiliki bobot pengorbanan dan pengabdian untuk keberhasilan usaha dan pencapaian cita-cita. Orang yang berintegritas dan berdedikasi merupakan orang yang al amānah dan al wafa' bi al 'ahdi - orang yang dapat dipercaya, setia, dan tepat janji. Dengan prinsip ini kredibilitas (kepercayaan) pun tentunya kembali akan terbangun. Dengan kata lain, khaira ummah akan dapat terwujud apabila al amānah dan al wafa' bi al'ahdi menjadi pilarnya.

Dalam kaitannya dengan dunia pendidikan, prinsip kedua ini tentunya akan melahirkan kesalingpercayaan, kesetiaan, integritas, dan dedikasi di antara pendidik, tenaga kependidikan, dan peserta didik di dalam menyelenggarakan proses pendidikan dan pengembangannya. Artinya bahwa proses transfer dan internalisasi keilmuan dan ketrampilan itu berjalan dan berkembang dalam situasi yang kondusif, dedikatif, dan penuh integritas. Penghargaan terhadap ilmu, sumber ilmu, dan masadepan ilmu pun dijunjung tinggi.

\section{c. Al 'adālab' ${ }^{13}$}

Al 'adâlah memiliki pengertian obyektif, proporsional dan taat asas. Butir prinsip ini berpegang kepada kebenaran obyektif, menempatkan segala sesuatu pada tempatnya secara proporsional, dan berpegang dengan taat pada azas-azas yang berlaku. Dengan prinsip ini distorsi penilaian yang mungkin dapat terjadi pun dapat dihindari sejauh mungkin. Selain itu, menurut Endang Turmudi ${ }^{14}$, implikasi lain dari prinsip al 'adâlah adalah lahir dan bersemayamnya kesetiaan kepada aturan main, rasionalitas dalam perbuatan keputusan, termasuk dalam persoalan penataan, penempatan, dan pemanfaatan sumberdaya yang ada.

Prinsip al 'adālah tidak semata menyangkut pada persoalan sumberdaya manusia (SDM). Prinsip ini juga menyangkut persoalan sumberdaya yang lain seperti sumberdaya alam (SDM) dan sumberdaya budaya (SDB). Obyektivitas, proporsionalitas, dan ketaatan pada azas dalam menegakkan keadilan dan kebenaran itu tentunya tetap mempertimbangkan beragam sumberdaya yang ada.

Dengan demikian, prinsip MKU al-'adālah merupakan prinsip dasar yang menempatkan obyektivitas pada kebenaran, proporsionalitas, dan ketaatan azas sebagai sendi utama. Ketiga prinsip dasar ini merupakan prinsip dasar untuk membentuk karakter pribadi seseorang secara individual maupun secara sosial-kemasyarakatan juga. Dengan kata lain, khaira ummah hanya dapat terbangun apabila al 'adālah ini menjadi pilarnya. Al 'adālah ini juga akan menciptakan sosok-sosok manusia yang memiliki kredibilitas (kepercayaan) yang tinggi yang jauh dari distorsi penilaian.

12 Abdul Mun'im, DZ, Piagam Perjuangan Kebangsaan, Jakarta: Setjen PBNU, NU Online, 2011, hal 60. 13 QS.16: 90 14 Endang Turmudi (Editor), Jejak Langkah NU dari Masa ke Masa, Jakarta, Luna Kreasindo, 2006, hal. 116. 
Dalam kaitannya dengan dunia pendidikan, dengan prinsip ketiga ini akan lahir sosoksosok yang kredibel dan jauh dari distorsi penilaian. Selanjutnya, dari ketiga prinsip dasar MKU di atas (al shidqu, al amānah wa alwafa' bi al-'ahdi, dan al 'adālah) dapat ditemukan kiranya sosok-sosok khaira ummah di dalam dunia pendidikan, yaitu sosok-sosok manusia pendidikan yang memiliki kredibilitas (kepercayaan) pada tingkatan yang tinggi.

\section{d. Al ta'äwun ${ }^{15}$}

Al ta'āwun ${ }^{16}$ merupakan sendi utama dalam tata kehidupan masyarakat. Sebagai makhluk sosial, tidak ada manusia yang dapat hidup sendiri tanpa bantuan pihak lain. Pengertian al ta'āwun meliputi tolong menolong, setia kawan dan gotong royong di dalam kebaikan dan taqwa. Imam al-Mawardi mengaitkan pengertian al birr (kebaikan) dengan kerelaan manusia dan takwa dengan ridla Allah SWT. Memperoleh keduanya berarti memperoleh kebahagiaan yang sempurna.

Al ta'āwun juga mengandung pengertian timbal balik dari masing-masing pihak untuk saling memberi dan menerima (take and give). Oleh karena itu, sikap al ta'āwun mendorong setiap orang untuk berusaha dan bersikap kreatif agar dapat memiliki sesuatu yang dapat disumbangkan kepada orang lain dan kepada kepentingan bersama. Altáāwun menjadikan seseorang hidup dinamis dengan lingkungannya, karena masing-masing akan menghargai, menerima dan menyempurnakan kekurangan orang dan pihak lain.

Al ta'äwun ini sudah menghadirkan sosok-sosok manusia berkredibilitas berhadapan dengan sosok/pihak lain di luar dirinya. Artinya, apabila ketiga konsep MKU sebelumnya lebih bersifat personal, maka konsep al ta'äwun ini sudah bersifat sosial dengan melibatkan sosoksosok lain di luar dirinya. Dimensi khaira ummah sudah tidak sekedar berada pada dimensi individual personal, akan tetapi sudah menyatukan sekaligus dimensi sosial. Artinya, sosoksosok berkredibilitas itu bersatu padu dengan sosok-sosok berkredibilitas lainnya, saling tolongmenolong, bersetia-kawan, bergotong royong dalam berbuat kebaikan dan taqwa, sekaligus menjauhi berbuat dosa dan permusuhan.

Dalam kaitannya dengan dunia pendidikan Islam, serangkaian uraian di atas dapat dibuat indikator awal khaira ummah, bahwa sosok-sosok dunia pendidikan yang berkredibilitas adalah:

1) yang menempatkan kebenaran dan kejujuran sebagai sendi utamanya,

2) yang memiliki integritas dan dedikasi,

3) yang menempatkan obyektivitas pada kebenaran, proporsionalitas, dan ketaatan azas sebagai sendi utamanya,

4) yang saling tolong-menolong, bersetia-kawan, bergotong royong dalam berbuat kebaikan dan taqwa, sekaligus menjauhi berbuat dosa dan permusuhan.

\section{e. Al istiqāmab ${ }^{17}$}

Al-istiqâmah mengandung pengertian atau ajeg, berkesinambungan, dan berkelanjutan.

\section{QS.5: 2}

16 Abdul Mun'im, DZ, Piagam Perjuangan Kebangsaan, Jakarta: Setjen PBNU, NU Online, 2011, hal 60.

17 QS.41: 30 
'Ajeg' artinya konsisten, konstan, dan tetap tidak bergeser dari jalur (thariqah) sesuai dengan ketentuan Allah SWT dan rasul-Nya, tuntunan yang diberikan oleh saläfu al-shālihb ${ }^{18}$ dan aturan main serta rencana-rencana yang disepakati bersama. 'Kesinambungan' artinya keterkaitan antara satu kegiatan dengan kegiatan yang lain dan antara satu periode dengan periode yang lain sehingga kesemuanya merupakan satu kesatuan yang tak terpisahkan dan saling menopang seperti sebuah bangunan. Sedangkan 'berkelanjutan' merupakan pelaksanaan kegiatan-kegiatan tersebut merupakan proses yang berlangsung terus menerus tanpa mengalami kemandekan, yang merupakan suatu proses maju (progressing) bukannya berjalan di tempat (stagnant).

Terkait dengan dunia pendidikan Islam, uraian panjang di atas dapat dibuat kelengkapan indikator dari khaira ummah, bahwa sosok-sosok dunia pendidikan yang berkredibilitas adalah :

1) yang menempatkan kebenaran dan kejujuran sebagai sendi utamanya,

2) yang memiliki integritas dan dedikasi,

3) yang menempatkan obyektivitas pada kebenaran, proporsionalitas, dan ketaatan azas sebagai sendi utamanya,

4) yang saling tolong-menolong, bersetia-kawan, bergotong royong dalam berbuat kebaikan dan taqwa, sekaligus menjauhi berbuat dosa dan permusuhan, dan

5) yang melaksanakan kesemuanya itu dengan konstan konsisten (ajeg), kontinyu, dan sustainabel.

Dalam dunia pendidikan (formal, nonformal, maupun informal), konsep dan nilai dalam MKU memiliki urgensi dan penting mendapatkan prioritas dalam proses penyelenggaraan dan pengembangan pendidikan itu sendiri. Dengan pemanfaatan konsep MKU bagi dunia pendidikan, maka diharapkan akan lahir, tumbuh, dan berkembang sosok-sosok dunia pendidikan berkarakter yang terdidik, yang istiqāmah di dalam menjunjung tinggi kebenaran dan kejujuran, memiliki integritas dan dedikasi, memiliki obyektivitas pada kebenaran, proporsionalitas, dan ketaatan pada azas yang berlaku, dan saling tolong-menolong, bersetiakawan, bergotong royong dalam berbuat kebaikan dan taqwa sekaligus menjauhi berbuat dosa dan permusuhan. Orientasi dan tujuannya jelas, yaitu pembentukan karakter masyarakat ideal, terbaik, berperadaban (khaira ummah) yang berbasiskan pribadi-pribadi paripurna (insan kamil) untuk mencapai kebahagiaan lahir batin dan dunia akhirat yang diridlai Allah Tuhan Yang Mahaesa.

\section{Pembahasan}

\section{Memahami Manajemen Pendidikan}

Secara umum dan normatif, manajemen ${ }^{19}$ sendiri adalah usaha mengatur organisasi untuk mencapai tujuan yang ditetapkan secara efektif, efisien, dan produktif. Efektif berarti mampu mencapai tujuan yang baik (doing the right thing), sedangkan efisien berarti melakukan sesuatu

18 Ulama terdahulu yang kredibel.

19 Ara Hidayat dan Imam Machali, Pengelolaan Pendidikan: Konsep, Prinsip, Aplikasi dalam Mengelola Sekolah dan Madrasah, Cetakan 1, Yogyakarta, Kaukaba, 2012, hal. 4. 
dengan benar (doing thing right). Secara fungsional menurut George R. Terry ${ }^{20}$, manajemen itu meliputi perencanaan (planning), pengorganisasian (organizing), menggerakkan/ menjalankan (actuating), dan pengawasan (controlling). Menurut George R. Terry ${ }^{21}$, manajemen adalah suatu proses (process) yang khas terdiri dari tindakan-tindakan perencanaan, pengorganisasian, penggerakan dan pengendalian yang dilakukan untuk menentukan serta mencapai sasaransasaran yang ditentukan melalui pemanfaatan sumber daya manusia (SDM) dan sumbersumber lainnya. Selain itu, manajemen juga merupakan seni (art) sebagaimana pendapat Mary Bakker Follet ${ }^{22}$, bahwa manajemen adalah the art of getting things done through people. Dengan demikian manajemen merupakan seni memberdayakan sumberdaya manusia (SDM) secara efektif, efisien, dan produktif melalui tindakan perencanaan, pengorganisasian, penggerakan, dan pengendalian untuk mencapai tujuan.

Dalam kaitannya dengan upaya pemberdayaan SDM organisasi, menurut Amin Widjaja Tunggal $^{23}$, manajemen akan memberikan beberapa manfaat, di antaranya: (a) aktivitasaktivitas formulasi strategi memperkuat kemampuan perusahaan untuk mengatasi masalah, (b) keputusan strategic yang didasarkan pada kelompok (group-based strategic decision) nampaknya diambil dari alternatif yang tersedia yang paling baik, (c) ketrampilan karyawan dalam formulasi strategi memperbaiki pemahaman mereka berhubungan dengan produktivitas ganjaran pada setiap rencana strategik dan dengan demikian akan mempertinggi motivasi, (d) celah dan saling tumpang tindih dalam aktivitas di antara individual dapat dikurangi karena partisipasi dalam formulasi strategi menjernihkan perbedaan peran, (e) resistensi berubah dapat dikurangi, walaupun peserta dalam formulasi strategi mungkin lebih senang dengan keputusan mereka sendiri daripada mereka harus menerima keputusan yang harus diterima secara paksa (authoritarian), kesadaran mereka yang lebih besar mengenai parameter yang membatasi opsi yang tersedia itu membuat mereka nampaknya lebih dapat menerima keputusan tersebut. Masih berkaitan dengan manajemen, John A. Pearce II dan Richard B. Robinson Jr. ${ }^{24}$ mengerucutkan pada pemahaman manajemen stratejik, bahwa manajemen stratejik adalah kumpulan keputusan dan tindakan yang merupakan hasil dari formulasi dan implementasi, rencana, yang didesain untuk mencapai tujuan suatu perusahaan, yang terdiri dari 9 tugas kritikal sebagai berikut: (a) menformulasikan misi perusahaan, termasuk pernyataan yang luas mengenai maksud (purpose), falsafah (philosophy), dan sasaran (goal), (b) mengembangkan suatu profil perusahaan (company profile) yang merefleksikan kondisi internalnya dan kemampuan, (c) menilai lingkungan eksternal perusahaan, termasuk baik faktor kompetitif maupun faktor yang berhubungan dengan konteks umum, (d) menganalisis opsi perusahaan dengan menandingi sumberdaya perusahaan dengan lingkungan eksternalnya, (e)mengidentifikasi opsi yang paling diinginkan dengan menilai setiap opsi dipandang dari sudut misi perusahaan, (f) memilih sekumpulan

20 Sondang P. Saigian, Manajemen Strategik, Jakarta, Bumi Aksara, 2008, hal 108.

21 Ara Hidayat dan Imam Machali, Pengelolaan Pendidikan: Konsep, Prinsip, Aplikasi dalam Mengelola Sekolah dan Madrasah, Cetakan 1, Yogyakarta, Kaukaba, 2012, hal. 3.

22 Wahjosumodjo, Kepemimpinan dan Motivasi, Jakarta, Ghalia Indonesia, 1987, hal.32.

23 Amin Widjaja Tunggal, Teori dan Kasus Manajemen Stratejik, Jakarta, Harvarindo, 2011, hal. 11-12.

24 Amin Widjaja Tunggal, Teori dan Kasus Manajemen Stratejik, Jakarta, Harvarindo, 2011, hal. 2-3 
tujuan jangka panjang dan strategi total (grand strategies) yang akan mencapai opsi yang paling diinginkan, (g) mengembangkan tujuan tahunan dan strategi jangka pendek yang sesuai dengan kumpulan tujuan jangka panjang yang dipilih dari strategi keseluruhan (grand strategies) itu, (h) mengimplementasikan pilihan strategi dengan alat alokasi sumberdaya yang dianggarkan, yaitu memadani tugas-tugas, manusia, struktur, teknologi, dan menekankan sistem ganjaran, dan (i) menilai keberhasilan proses stratejik sebagai masukan untuk pengambilan keputusan di masa yang akan datang.

Adapun manajemen pendidikan sendiri, menurut GZ Roring ${ }^{25}$, adalah cara bekerja dengan orang-orang di dalam rangka usaha mencapai tujuan pendidikan yang efektif, yang berarti mendatangkan hasil yang baik, tepat dan benar sesuai dengan tujuan pendidikan yang telah ditetapkan. Manajemen pendidikan juga dapat berarti sebagai pelaksanaan pemimpin yang mewujudkan aktivitas kerjasama yang efektif bagi tercapainya tujuan pendidikan. Ia dapat juga berarti semua kegiatan dari yang meliputi usaha-usaha besar seperti mengenai perumusan policy, pengarahan usaha, koordinasi, konsultasi, korespondensi, control perlengkapan dan seterusnya sampai kepada usaha-usaha kecil dan sederhana. Sedangkan Husaini Usman 26 mendefinisikan manajemen pendidikan sebagai seni dan ilmu mengelola sumber daya pendidikan untuk mewujudkan suasana belajar dan proses pembelajaran agar peserta didik secara aktif mengembangkan potensi dirinya untuk memiliki kekuatan spiritual keagamaan, pengendalian diri, kepribadian, kecerdasan, akhlak mulia, serta ketrampilan yang diperlukan dirinya, masyarakat, bangsa, dan negara. Berdasarkan fungsi-fungsi manajemen, manajemen pendidikan juga dapat diartikan sebagai proses perencanaan, pengorganisasian, pelaksanaan, dan pengendalian sumber daya pendidikan untuk mencapai tujuan pendidikan yang efektif dan efisien.

Dalam kaitannnya dengan 9 tugas kritikal manajemen stratejik di atas, tugas manajemen pendidikan berarti menyangkut keharusan untuk mampu menformulasi visi dan misi kependidikan dalam sebuah konstruksi dan representasi sebuah identitas budaya, mampu mengembangkan profil dan grand strategies, yang berkaitan dengan tugas perencanaan, pengorganisasian, pengarahan/pelaksanaan, dan pengendalian. Manajemen pendidikan berarti kemampuan stratejik untuk merencanakan, mengorganisir, melaksanakan, dan mengendalikan seluruh komponen untuk mencapai tujuan secara efektif, efisien, dan produktif, untuk masa kini dan masa mendatang. Manajemen pendidikan lebih sebagai manajemen stratejik tentang sikap, pandangan hidup, dan komitmen. Manajemen pendidikan pun tentunya memiliki seni (art) yang tidak sebatas memberdayakan sumber daya manusia (SDM) yang ada di dalam sebuah lingkungan budaya terbatas saja, akan tetapi manajemen pendidikan juga merupakan seni yang kreatif yang menuntut manajer (pemimpin, kepala sekolah) untuk bermain peran secara apik dan stratejik bagi dirinya sendiri dan sekaligus memainkan peran-peran yang layak bagi orangorang di sekelilingnya di dalam satu kesatuan sosial budaya yang menjadi tanggungjawabnya.

25 Ara Hidayat dan Imam Machali, Pengelolaan Pendidikan: Konsep, Prinsip, Aplikasi dalam Mengelola Sekolah dan Madrasah, Cetakan 1, Yogyakarta, Kaukaba, 2012, hal. 5

26 Husaini Usman, Manajemen Pendidikan, Yogyakarta, PPs UNY, 2004, hal.6 
Dari uraian panjang di atas dapat ditarik pemahaman bahwa sebuah lembaga pendidikan sekolah dan lainnya adalah konstruksi dan representasi dari sebuah identitas budaya. Kebudayaan adalah lingkungan aktual untuk berbagai praktek, representasi, bahasa, dan adat-istiadat dari masyarakat tertentu. ${ }^{27}$ Di dalamnya terdapat elemen-elemen budaya yang terartikulasikan, termasuk di dalamnya menyangkut ideologi. Persoalan konstruksi dan representasi merupakan persoalan manajemen. Persoalan budaya dan identitasnya merupakan persoalan keberlangsungan hidup yang memerlukan proses internalisasi edukasional. Manajemen pendidikan merupakan persoalan aktual-konstruksional dan aktikulatif-representatif dari proses kebudayaan yang bersifat siklik di ranah pendidikan sejak kegiatan perencanaan, pengorganisasian, pelaksanaan, sampai dengan pengawasan dan evaluasi terhadap kegiatan kependidikan di dalam suatu lembaga pendidikan seperti sekolah, madrasah, pesantren, bahkan di dalam suatu komunitas dan masyarakat tertentu, yang bertumpu pada pemberdayaan sumberdaya pendidikan khususnya SDM. Pendek kata, manajemen pendidikan adalah manajemen kebudayaan di ranah pendidikan, baik di dalam lembaga pendidikan formal, nonformal, bahkan di dalam komunitas dan masyarakat dengan memberdayakan secara stratejik terhadap SDM dan sumberdaya lainnya untuk mencapai tujuan secara efektif, efisien, dan produktif, dengan motor penggerak utama kepala sekolah sebagai pemimpin.

Persoalan manajemen adalah persoalan kepemimpinan, persoalan kemampuan seorang pemimpin (manajer, kepala sekolah, dan sebutan lain) di sebuah lembaga seperti sekolah, madrasah, pesantren, sanggar, keluarga, dan masyarakat pada umumnya. Persoalan manajemen pendidikan berarti menunjuk pada bagaimana kepemimpinan dalam sebuah lembaga pendidikan itu. Manajemen pendidikan semacam sekolah merupakan persoalan kemampuan seorang kepala sekolah dalam memimpin dan mengelola sekolah yang dipimpinnya. Berkait dengan model kepemimpinan dalam hubungannya dengan keberadaan kepala sekolah di dalam lembaga pendidikan, Muhammad Syafii Antonio ${ }^{28}$ menjelaskan berkaitan dengan apa yang disebut dengan Prophetic Leadership and Management Wisdom (kearifan kepemimpinan dan manajemen nabawi) yang disingkat dengan Pro-LMWisdom. Model ini merupakan suatu model kepemimpinan yang berupaya menyusun strategi tercapainya kesuksesan secara seimbang, baik bisnis, keluarga, sosial, maupun spiritual, berdasarkan pada suri tauladan kepemimpinan dan manajemen Nabi Muhammad SAW serta semangat asmäul husna (nama-nama Allah SWT). Ada empat sasaran utama yang hendak dicapai melalui model pro- $L M$ ini, yaitu: (1) terbentuknya pribadi paripurna (insan kāmil) atau personal excellence yang bersumber pada ajaran tauhid dan berintegritas tinggi. Suri tauladan dari pribadi unggul ini tercermin dari sifat shiddì $q$ Nabi SAW. Sifat shiddì ini menurut kata asalnya berarti selalu berlandaskan kepada kebenaran terutama keimanan yang benar (tauhid). Keimanan yang benar akan melahirkan sikap, perilaku, dan tindakan yang benar. Pada gilirannya, seseorang yang mengamalkan sifat ini akan dikenal sebagai pribadi yang berintegritas tinggi, (2) terbentuknya inter-personal capital, yaitu harmonisnya

27 Chris Barker, Culture Studies, Teori dan Praktek, terjemahan Nurhadi, Yoyakarta, Kreasi Wacana, 2015, hal. 8

28 Muhammad Syafi'i Antoni, Ensiklopedia PROLM: Prophetic Leadership and Management Wisdom, Jakarta, Tazkia Publishing, 2013, 3-4 
hubungan antar sesama manusia dalam berbagai lingkungan sosial seperti keluarga, lingkungan tempat tinggal, bisnis, dan sebagainya, berdasarkan rasa saling percaya (mutual trust). Suri tauladan ini dikembangkan dari sifat luhur amānah Nabi SAW. Sifat ini secara harfiah berarti terpercaya, merupakan modal utama dalam membangun social trust yang semakin langka belakangan ini, (3)munculnya kemampuan teknis dan manajerial (profesioalism and technical competence), atau dorongan untuk menjadi insane yang kompeten dengan menguasai ilmu pengetahuan, ketrampilan teknis, serta menjunjung tinggi profesionalisme dan good corporate governance. Technical competence ini dibentuk dengan menguarai unsur-unsur pembentuk sifat fathänah Nabi SAW, dan (4) leadership wisdom atau kearifan dan seni kepemimpinan. Hal ini dapat dicapai dengan mengoptimalkan kemampuan berkomunikasi dalam memimpin dengan visi, misi, dan pendelegasian wewenang yang jelas serta team-work yang solid. Rasulullah mencontohkan hal ini dengan penerapan sifat tabligh terhadap para sahabat yang merupakan kolega, asisten, staf, mitra, serta team-work beliau dalam merealisasikan tujuan dan sasaran perjuangannya.

\section{Manajemen Pendidikan Karakter di SMK Maarif 2 Gombong}

Hasil penelitian di SMK Maarif 2 Gombong Kabupaten Kebumen terkait manajemen pendidikan karakter mabadi khaira ummah (MKU) memperlihatkan pola manajemen yang efektif, efisien, dan produktif. Sekolah sebagai lembaga budaya berperan aktif di dalam melestarikan dan mengembangkan nilai-nilai budaya luhur yang termaktub dalam lima prinsip MKU (al shidqu, al amānah wa al wafa' bi al'ahdi, al ta'āwun, al 'adālah, al istiqāmah). Kepala sekolah mempertunjukkan kemampuan manajerialnya dengan menghidupkan visi sekolah "menyiapkan siswa unggul dalam prestasi berdasarkan iman dan taqwa" selaras dengan prinsip MKU dan tradisi-tradisi yang lazim hidup di dalam masyarakat Gombong dan sekitarnya dimana para civitas akademika SMK Maarif 2 Gombong tinggal dan hidup bermasyarakat dan berbudaya. Secara kurikuler, MKU memang terinternalisasi melalui pembelajaran Ke-NU-an, akan tetapi kemudian MKU juga terinternalisasikan bersamaan dengan menghidupkan tradisitradisi luhur yang hidup di tengah masyarakat. Berikut bentuk-bentuk kegiatan internalisasi nilai dan prinsip MKU yang bersifat kultural non-kurikuler yang terkelola dan melibatkan serta mempengaruhi segenap civitas akademika.

a. Tradisi penjemputan peserta didik di pintu gerbang masuk sekolah tiap pagi oleh Kepala Sekolah, Wakil Kepala Sekolah, dan Guru, bersalam-salaman, dan tradisi cium-tangan guru. Siswa merasa dihargai kedatangannya, dan mereka berusaha untuk dating gasik tidak terlambat.

b. Tradisi mengumandangkan asmaulhusna, shalawat nariyah, dan doa belajar di kelas masing-masing bersama guru pengajar jam pertama. Tradisi ini sangat membekas terkait keimanan dan penghormatan kepada ilmu pengetahuan.

c. Tradisi membaca Surat Yasin tiap hari Jumat pagi/siang sebelum kegiatan pembelajaran dimulai, di kelas, bersama guru pengajar jam pertama, dan dilanjutkan infak Jumat yang hasilnya diperuntukkan guna saling membantu/menyumbang siswa terkena musibahal. 
d. Tradisi membaca Surat Al 'Asyr untuk mengakhiri kegiatan pembelajaran di kelas yang mengandung makna mendalam saling mengingatkan perihal keimanan, kesalehan, kebenaran, dan kesabaran. Kemudian siswa bersalam-salaman sesama teman dan dengan gurunya.

e. Tradisi mondok di Pondok Pesantren An Nahdliyah SMK Maarif 2 Gombong, dan latihan mondok di berbagai pondok pesantren di Kabupaten Kebumen dan sekitarnya untuk mengaji pada kyai, belajar hidup sederhana di pondok pesantren, dan bermasyarakat.

f. Tradisi pembinaan dan pengajian bersama dengan Komite Sekolah melalui rapat pembinaan dengan materi keIslaman dan persekolahan.

Secara kultural, manajemen pendidikan berlangsung hidden curriculum model menyatu dengan kegiatan-kegiatan. Meskipun demikian, pada tahap perencanaan Kepala Sekolah tetap melibatkan Wakil Kepala Sekolah, kemudian mensosialisasikannya kepada segenap guru dan karyawan, melaksanakannya bersama segenap civitas akademika, dan Kepala Sekolah melalui wakil-wakilnya melaksanakan pengawasan, kemudian dilakukan evaluasi bersama melalui rapatrapat yang diselenggarakan.

Gambar 1 menunjukkan bagaimana manajemen pendidikan dibangun antar komponen dalam sekolah melalui kekayaan tradisi lokal. Kepala sekolah membangun pola koordinasi dan pendelegasian tugas dan wewenang kepada wakil-wakilnya pada masing-masing kegiatan. Artinya, bahwa di SMK Maarif 2 Gombong berlangsung manajemen pendidikan yang sekaligus merupakan manajemen budaya, yang menunjukkan bagaimana kurikulum sekolah dan visi sekolah hidup dan berlangsung secara factual model maupun hidden model.

Persoalan pendidikan karakter itu merupakan amanat nasional sebagaimana tertuang dalam Undang Undang RI Nomor 20 Tahun 2003 tentang Sistem Pendidikan Nasional, Pasal 3, bahwa: "pendidikan nasional berfungsi mengembangkan kemampuan dan membentuk watak serta peradaban bangsa yang bermartabat dalam rangka mencerdaskan kehidupan bangsa, bertujuan untuk berkembangnya potensi peserta didik agar menjadi manusia yang beriman dan bertakwa kepada Tuhan Yang Mahaesa, berakhlak mulia, sehat, berilmu, cakap kreatif mandiri, dan menjadi warga Negara yang demokratis serta bertanggungjawab". Dalam kaitannya dengan pendidikan karakter ini, NU - sebagai payung organisasi SMK Maarif 2 Gombong - jelasjelas menempatkan tujuan utama pendidikan adalah akhlāqul karimah sebagaimana tujuan pendidikan karakter ${ }^{29}$. Adapun tahapan pendidikan karakter melalui tahapan pengembangan (knowing), pelaksanaan (acting), dan kebiasaan (habit) ${ }^{30}$. Karakter dasar yang ingin dibangun adalah manusia-manusia Indonesia yang beriman, bertakwa, dan berakhlak mulia. Karakter dasar ini tentunya harus melalui tahapan knowing, acting, dan habit. Di SMK Maarif 2 Gombong pendidikan karakter ini sudah dilakukan dan sesuai tahap. Pada tahapan habit, segenap civitas akademika malahan sudah membiasakan diri membangun pendidikan karakter melalui tradisi-tradisi lokal sebagaimana sudah dijelaskan di atas.

29 Agus Salim Chamidi, "Membedah Eksistensi Nahdlatul Ulama dalam Pembangunan Pendidikan Karakter Bangsa”, dalam Jurnal An Nidzam, Volume I, Nomor 2, IAINU Kebumen, Mei-Agustus 2014, hal.240-247.

30 Heri Gunawan, Pendidikan Karakter Konsep dan Implementasi, Cetakan 2,Bandung, Alfabeta, 2012, hal.38. 


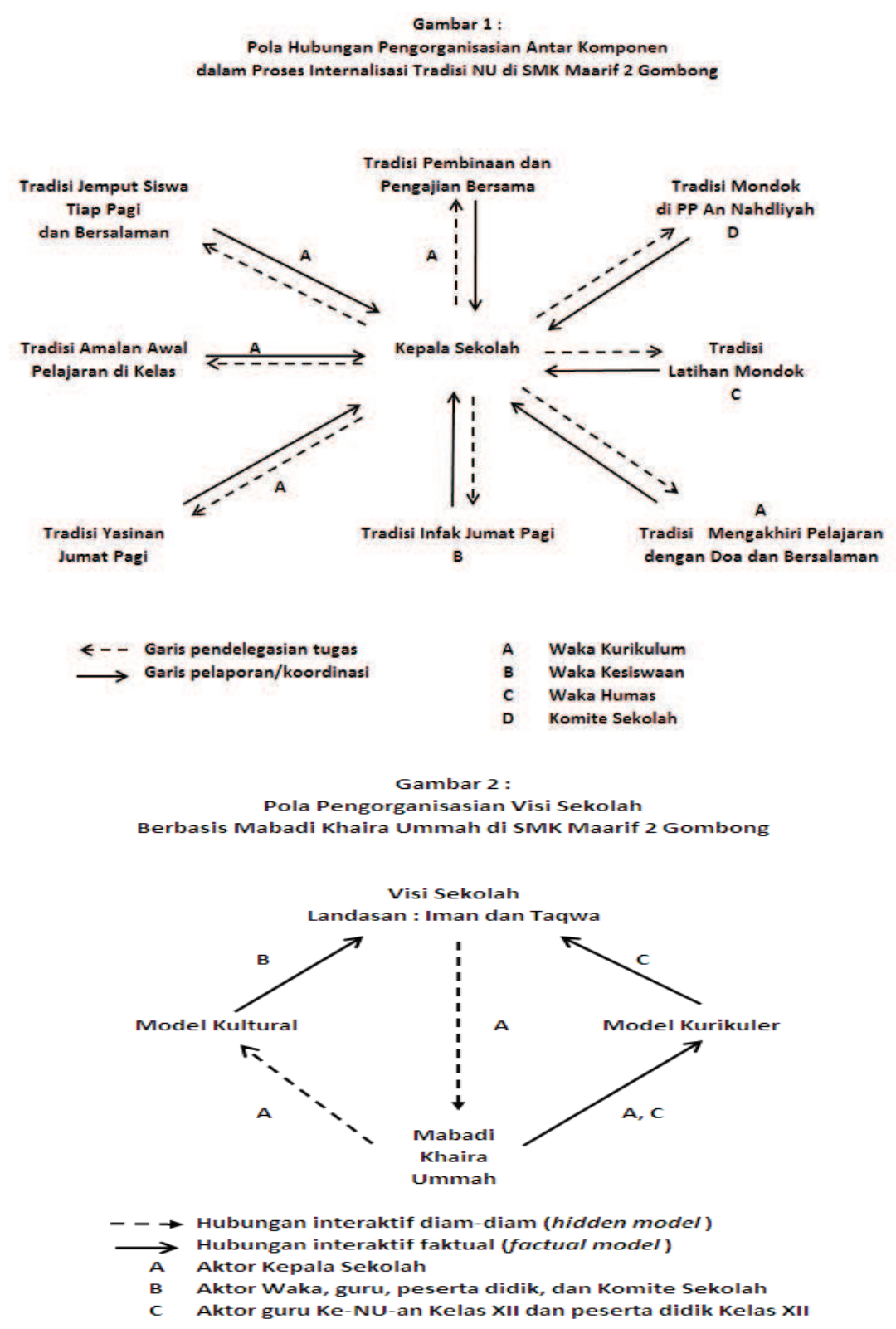

Gambar 2 dan 3 jelas memperlihatkan bagaimana visi sekolah "menyiapkan siswa unggul dalam prestasi berdasarkan iman dan taqwa" sebagai visi pendidikan berkarakter dan sekaligus sebagai pancaran dari nilai-nilai budaya yang dianutnya itu dikontruksi, diaktualisasikan, dan direpresentasikan selaras dengan prinsip MKU melalui model kultural maupun kurikuler. Pengorganisasian adalah ruh dari manajemen, dan pola pengorganisasian visi sekolah melalui aktualisasi prinsip-prinsip MKU pun melibatkan segenap civitas akademika SMK Maarif 2 Gombong. Tujuannya adalah pembentukan pribadi-pribadi paripurna (insan kamil) dan secara masif adalah pembentukan masyarakat ideal terbaik berperadaban (mabadi khaira ummah). 


\section{E. Kesimpulan}

Dari uraian panjang di atas, penelitian tentang pendidikan karakter mabadi khaira ummah di SMK Maarif 2 Gombong di Kabupaten Kebumen, mendapatkan kesimpulan bahwa :

1. Manajemen pendidikan karakter mabadi khaira ummah (MKU) diselenggarakan dimana kepala sekolah selaku pemimpin (manajer) telah melakukan terobosan besar dengan merekonstruksi, mengaktualisasikan, dan merepresentasikan, serta membangun polanya melalui tradisi-tradisi lokal sebagai bentuk hidden model di luar factual model.

2. Kepala sekolah merepresentasikan visi sekolah melalui manajemen pendidikan karakter MKU untuk tujuan pembentukan insan kamil dan sekaligus mabadi khaira ummahal.

3. Pengorganisasian sebagai ruh manajemen berlangsung melibatkan segenap civitas akademika.

\section{Bibliografi}

Abdul Mun'im, DZ, Piagam Perjuangan Kebangsaan, Jakarta: Setjen PBNU, NU Online, 2011

Agus Salim Chamidi, Membedah Eksistensi Nahdlatul Ulama dalam Pembangunan Pendidikan Karakter Bangsa, dalam Jurnal An Nidzam Jurnal manajemen Pendidikan dan Studi Islam, Volume I, Nomor 2, Pascasarjana Magister Pendidikan Islam Institut Agama Islam Nahdlatul Ulama (IAINU) Kebumen, Mei-Agustus 2014.

Al-Qur'an dan Terjemahnya, Departemen Agama RI, 1984.

Amin Widjaja Tunggal, Teori dan Kasus Manajemen Stratejik, Jakarta, Harvarindo, 2011

Anggaran Dasar Nahdlatul Ulama (AD-NU), Hasil Muktamar 32 di Makassar,tahun 2010

Ara Hidayat dan Imam Machali, Pengelolaan Pendidikan: Konsep, Prinsip, Aplikasi dalam Mengelola Sekolah dan Madrasah, Cetakan 1, Yogyakarta, Kaukaba, 2012

Atabik Ali dan Ahmad Zuhi Muhdlor, Kamus Krapyak Al-Ashri Arab Indonesia, Cetatakan 2, UD Multi Karya Grafika Yogyakarta , 1997

Chris Barker, Culture Studies, Teori dan praktek, terjemahan Nurhadi, Yogyakarta, Kreasi Wacana, 2015.

Endang Turmudi (Editor), Jejak Langkah NU dari Masa ke Masa, Jakarta : PT Luna Kreasindo, 2006

Faojin M dan Noor Kholis, Ke-NU-an dan Ablussunah Waljamaah MA/SMA/SMK Kelas XII, Lembaga Pendidikan Maarif NU Jawa Tengah, 2011 
Heri Gunawan, Pendidikan Karakter Konsep dan Implementasi, Cetakan 2, Bandung, CV Alfabeta, 2012

Husaini Usman, Manajemen Pendidikan, Yogyakarta, PPs UNY, 2014

Made Pidarta, manajemen Pendidikan Indonesia, Jakarta, Bian Aksara, 1998.

Muhaimin, Paradigma Pendidikan Islam, Upaya Mengefektifkan Pendidikan Agama Islam di Sekolah, Bandung, Remaja Rosdakarya, 2004.

Muhammad Syafii Antonio, Ensiklopedia PROLM: Prophetic Leadership and Management Wisdom, Jakarta, Tazkia Publishing, 2013.

Sondang P. Siagian, Manajemen Strategik, Jakarta, Bumi Aksara, 2008.

Sudiyono, Metode Penelitian Manajemen, Cetakan 1, Bandung, Alfabeta, 2013

Undang Undang Sistem Pendidikan Nasional, UU Sisdiknas Tahun 2003

Wahjosumidjo, Kepemimpinan dan Motivasi, Jakarta: Ghalia Indonesia, 1987. 
